\title{
ASSESSMENT OF OPERABILITY OF MAINTAINABLE CROSSPIECE
}

\author{
Alexander Pastukhov ${ }^{1}$, Eugeny Timashov ${ }^{2}$, Tatyana Parnikova ${ }^{1}$ \\ ${ }^{1}$ Belgorod State Agricultural University named after V. Gorin, Russia; \\ ${ }^{2}$ Belgorod University of Cooperation, Economics and Law, Russia \\ pastukhov_ag@mail.ru, timachov@mail.ru,t-parnikova@mail.ru
}

\begin{abstract}
Ensuring operability of transport technological machines is connected with increase in characteristics of non-failure operation, durability and maintainability of transmission units, in particular, of drive lines. The analysis of trends of improvement of designs and technological processes of maintenance operation of drive lines shows that designs of joints with maintainable crosspieces and bearing mount assemblies are perspective. Besides, developments of technical solutions on realization of automated maintenance operation of bearing mount assemblies on the basis of control of their valid technical condition are perspective. Results of comparative assessment of operability of maintainable and serial crosspieces of asynchronous cardan joints on the example of the IV standard size on RD 37.001.665-96 are presented in the article. In the course of probes graphic 3D-models of serial and maintainable crosspieces in the computer-aided engineering system of KOMPAS-3D CAD-technologies are made. In connection with complexity of design for the purpose of increase in reliability of estimation of the crosspieces strength and stiffness, test calculations are performed on the basis of the CAE-technology by means of applied library of the final and element analysis of automated workplace of FEM for KOMPAS-3D. When evaluating the intense deformed condition of serial and maintainable crosspieces, comparative calculations of parameters at the modes of nominal operational loading are performed. The final results were estimated in sizes of equivalent normal tension, total deformations and the safety factor on fatigue strength at bend. In calculation result conclusions about the working capacity and prospects of the offered design and mode of maintenance operation of cardan joints are confirmed.
\end{abstract}

Keywords: operability, crosspiece, joint, strain-stress state.

\section{Introduction}

The operability of technical systems in operation is defined by their reliability, which is put at the design stage of products, provided at production, implemented when using to destination and is maintained at maintenance operation and repair in operation [1]. In relation to all-machine-building power units (clusters) of mechanical transmissions of transport and technological machines, for example, to joints of drive lines, insufficient reliability in operation caused by low durability and limited maintainability is noted [2].

The problem of ensuring operability of joints of drive lines is supposed to be solved in the most perspective direction by increase in maintainability of units on the basis of development of the "selfserved", "self-repairing" and "self-regulating" designs with use of the technology of automatic maintenance operation. At the same time, it is necessary to consider a number of design, technological and operational features of cardan bearing mount assemblies: console arrangement, unilaterally perception of loading, uneven load distribution between swing bodies, distinction of mechanical properties of the crosspiece and bearing crosspin, mode of the rocking motion, influence of centrifugal forces of inertia $[2 ; 3]$.

Patent probes of technical solutions of cardan joints by results of probes of scientists and practicians have shown existence of methods of automatic regulation of their technical condition, which should be classified in three groups:

1. method of automatic compensation of wear of detail work surfaces (for example, copyright certificate - SU 431334, SU 471480 and patents - RU 2453451, RU 2075878, RU 2106548, RU 2205304, RU 2220338, RU 2234008, RU 2232309, RU 2238446, etc.);

2. method of optimization of temperature condition of bearing mount assemblies (for example, copyright certificate SU 1712699 and patent RU 2453744, etc.);

3. method of ensuring automatic greasing of bearing mount assemblies (for example, patents RU 2224918, RU 2453744, etc.).

Autocompensation of wear is carried out by automatic reduction of radial play in the bearing mount assembly and replacement of worn-out surfaces by not worn-out. The technical essence of the method consists in introduction of not worn-out surfaces of details of cardan bearing mount assemblies (RU 2453451, RU 2075878, etc.) in the work area. Optimization of the temperature condition consists 
in ensuring effective offtake of warmth from the zone of contact of rolling elements (RU 2453744, etc.), at the same time, the process of annealing and self-tempering of work surfaces of crosspins of the crosspiece and bearings is prevented. Providing of self-lubrication of bearing mount assemblies (RU 2224918, etc.) is accompanied by optimization of the temperature condition as heat removal is one of the functions of grease [4].

In practice of designing power knots of transport and technological machines the most perspective method of probe and justification of design and functional data, for example, of drive shafts is the numerical method on the basis of assessment of the intense deformed state by means of engineering CAE-systems [5;6].

The research objective - increase in maintainability of the cardan joint with adaptation to the technology of automatic service on the basis of instruments of automated design.

For achievement of the goal it is necessary to solve the following problems:

1. development of maintainable design of the cardan joint with the automatic lubricating system;

2. constructive and technological engineering analysis of parameters of strength and stiffness of the 3D-model of maintainable design of the cardan joint;

3. comparison of parameters of the intense deformed condition of serial and maintainable cardan crosspieces in the conditions of operational loading.

\section{Materials and methods}

The existing design of the serial crosspiece of the cardan joint has the lubricating system, which is served manually by the operator and possesses pronounced shortcomings of type of low reliability and high labor input of the maintenance operation.

In the field of improvement of cardan joint designs technical solutions to shortcomings which they carry are known: distinction of conditions of greasing of each of four needle bearers; dependence of conditions of greasing on the rotary speed of the joint, without its technical condition and residual resource; impossibility of implementation of automatic greasing, unsatisfactory conditions of bearing mount assemblies lubrication and manual mode of maintenance operation (SU 211965, SU 274670, SU 475465, SU 1712699).

System approach to solution of the problem of increase in durability on the basis of the method of automatic maintenance operation assumes development of classification (Fig. 1), which contains the systematized data on options of cardan joints design application and methods of automatic maintenance operation at the level of patent decisions [7].

The analysis of the data shows that the groups of methods of autocompensation of wear mentioned above (RU 2220338 - by installation of the maintainable elastic barrel, SU 471480 - due to continuous rolling of a set of rollers with the separator on the pin circle), optimization of the temperature condition (SU 1249217 - application of aluminum edges of cooling, SU 1712699 arrangement of the heat-exchanging cylinder in cavities of pins of crosspieces) and automatic greasing (SU 211965 - by installation in ports of lubricant of pins of the sprung buckets with the axial port, RU 2453744 - with the additional system of ports and arrangements in them of the filling agent having ability to expansion at temperature increase of the knot) are realized in technical solutions at the level of inventions, however, problems of justification of the design data and carrying out comparative assessment of the strength and stiffness pilot and serial designs are not solved.

The technical essence of the offered design RU 2453744 is that the crosspiece of the cardan joint (Fig. 1) contains two systems of ports and the reservoir filled with a lubricant and filling agent, the last at critical temperature increase of the unit squeezes out with the bucket portion of the lubricant in the space of the bearing mount assembly in the automatic mode.

As a filling agent it is recommended to use the substance applied in production of thermostatically controlled chambers of liquid automobile cooling systems - mixture of ceresin and copper powder, wherein the necessary quantity of the filling agent is determined by formula [8]

$$
m_{n}=V \cdot \frac{\rho_{S} \rho_{L}}{\rho_{S}-\rho_{L}},
$$


where $m_{n}$ - mass of the filling agent, $\mathrm{kg}$;

$V$ - replacement volume, $\mathrm{m}^{3}$;

$\rho_{S}$ - firmness of the filling agent in solid phase, $\mathrm{kg} \cdot \mathrm{m}^{-3}$;

$\rho_{L}$ - firmness of the filling agent in liquid phase, $\mathrm{kg} \cdot \mathrm{m}^{-3}$.
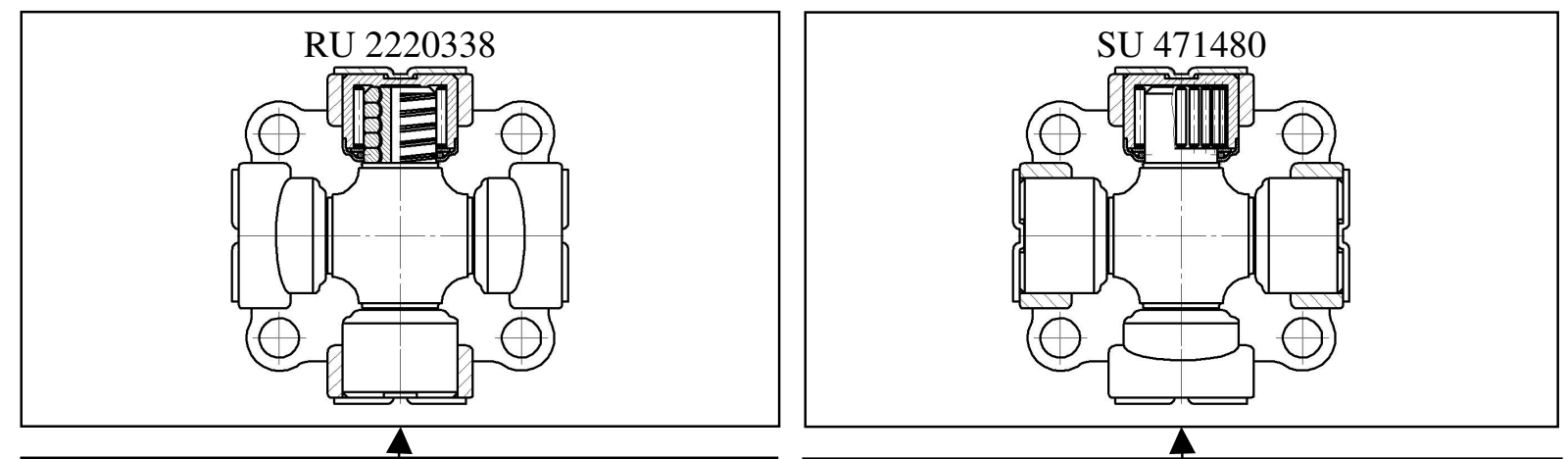

Reduction of radial play

4

Replacement of work surfaces

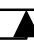

Autocompensation of wear of work surfaces of bearing unit details

Methods of ensuring maintainability on the basis of automatic service of bearing mount assemblies of cardan joints

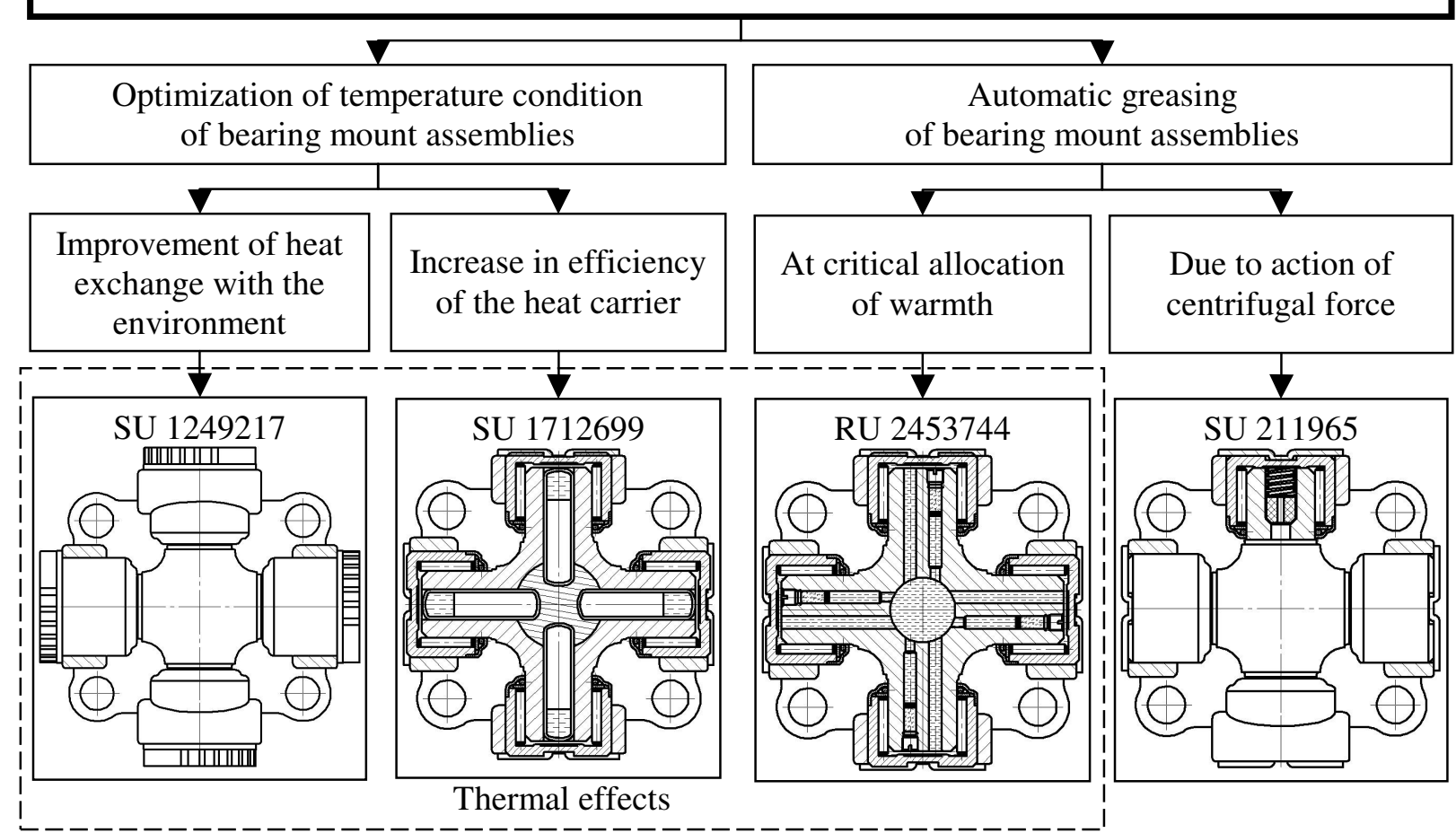

Fig. 1. Classification of realization of methods of ensuring maintainability of cardan joints on basis of technology of automatic maintenance operation

Performance of additional ports in the body of the crosspiece changes the strength and stiffness of the characteristics, therefore, it is feasible to do comparative test calculations on the basis of the method of the final and element analysis, where as the object of probe we will consider the cardan joint IV of a standard size on RD 37.001.665-96, and in the form of the settlement tool we use the working APM FEM module of the KOMPAS-3D CAD-system.

For carrying out engine calculations it is necessary to determine the radial force $F_{\mathrm{r}}, \mathrm{N}$, acting on the crosspiece pin, formula [8;9] 


$$
F_{r}=T_{n} / l
$$

where $T_{n}$ - nominal torque, $\mathrm{N} \cdot \mathrm{m}$;

$l$ - distance between the midpoints of two opposite pins, $\mathrm{m}$.

The radial evenly distributed loading $q_{\mathrm{r}}, \mathrm{N} \cdot \mathrm{m}^{-1}$, on the crosspiece pin is determined by formula [7]

$$
q_{r}=F / l_{1},
$$

where $l_{1}-$ crosspiece pin length, $\mathrm{m}$.

\section{Results and discussion}

The design of the serial $(a)$ and offered maintainable $(b)$ crosspieces is given in Fig. 2. For the maintainable crosspiece at the approach of limit condition of any of the bearing mount assemblies located on pins 2 of crosspieces 1 there is critical increase in temperature that leads to expansion of the filling agent 4 , which presses the bucket 5 exerting pressure upon grease in ports 3 and 6 , therefore lubricant through reservoir 7 gets to needle bearers.
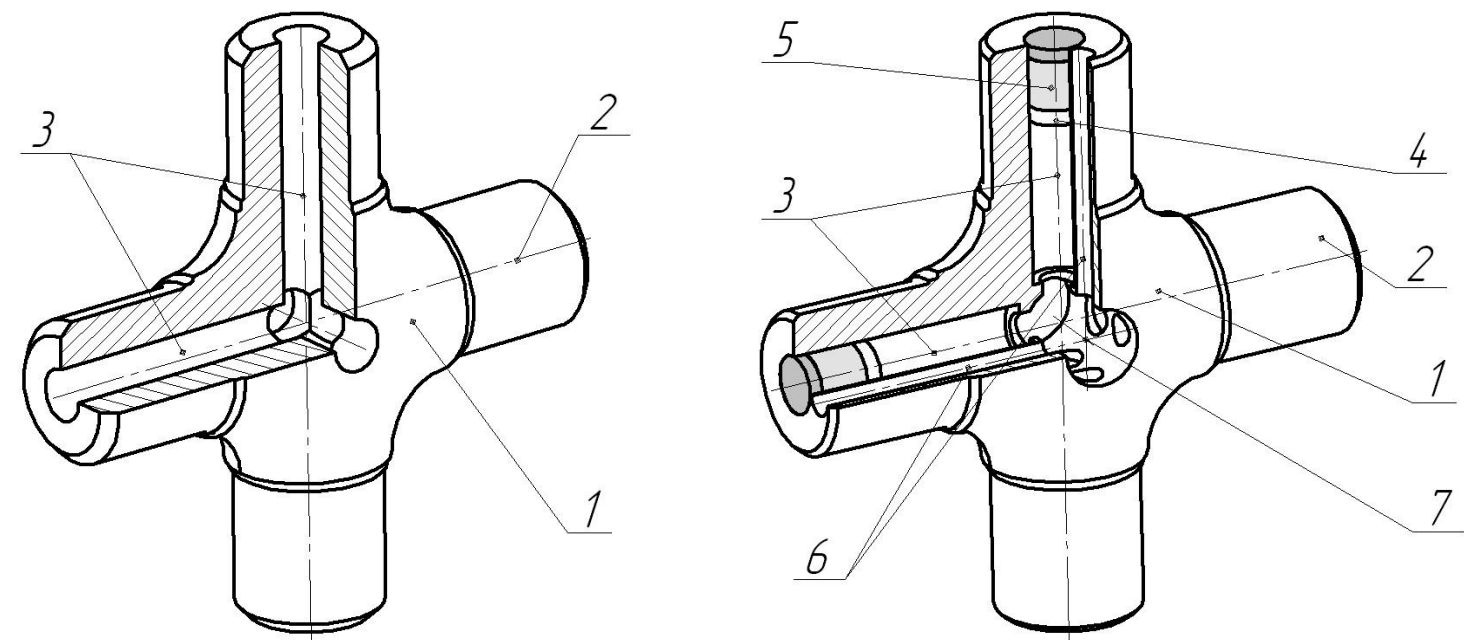

Fig. 2. Maintainable crosspiece of cardan joint: 1 - crosspiece; 2 - pin; 3 - lubricant ports; 4 - bucket; 5 - filling agent; 6 - additional ports; 7 - reservoir

At justification of the crosspiece parameters we proceed from the condition that for full replacement of lubricant the volume of replacement of lubricant has to be equal to the volume of the cavity of the bearing mount assembly $\left(0.99 \mathrm{~cm}^{3}\right.$ for IV standard size crosspiece). At the same time, firmness of solid phase of ceresin is $0.91 \mathrm{~g} \cdot \mathrm{cm}^{-3}$ at $15^{\circ} \mathrm{C}$, and liquid phase $-0.48 \mathrm{~g} \cdot \mathrm{cm}^{-3}$ at $95^{\circ} \mathrm{C}$, then in formula (1) we receive $m_{n}=1.01 \mathrm{~g}$. Thus, the filling agent volume in solid state is $1.01 / 0.91=1.11 \mathrm{~cm}^{3}$, at achievement of critical temperature $-1.01 / 0.48=2.1 \mathrm{~cm}^{3}$. Proceeding from the received results, we design the camera (poses. 6 Fig. 2) for the filling agent of cylindrical form: camera volume $-2.1 \mathrm{~cm}^{3}$, available length $-38 \mathrm{~mm}$, cap thickness $-2 \mathrm{~mm}$, bucket height $-2 \mathrm{~mm}$, diameter of the camera $-9 \mathrm{~mm}$; the necessary volume of lubricant is equal to $-0.99 \cdot 4=3.96 \mathrm{~cm}^{3}$; we accept the diameter of lubricant ports for reasons of technological effectiveness of production: when the drilling depth should not exceed the diameter more than 8 times, that is $-38 / 8=4.75 \mathrm{~mm}$.

For carrying out calculations 3D-models of serial and maintainable crosspieces in the graphic editor of KOMPAS-3D are created (Fig. 3), on which the final and element grid is applied and design loads (APM FEM) are applied: cardan joint of the car GAZ - 3308 transfer the nominal torque of $T_{n}=652 \mathrm{~N} \cdot \mathrm{m}$ at rotary speed of $n=992 \mathrm{~min}^{-1}$. On formula (2) at $l=0.07 \mathrm{~m}$ we receive force $F_{r}=9314 \mathrm{~N}$, then at $l_{1}=0.02 \mathrm{~m}$ the distributed loading is received of $q_{r}=466 \mathrm{kN} \cdot \mathrm{m}^{-1}$. Material and mechanical properties of crosspieces are accepted the following: steel 20H GOST 4543-2016 (20Cr4 $\mathrm{EN}$ ); fluidity limit $\sigma_{y}=400 \mathrm{MPa}$, module of longitudinal elasticity of $E=216 \mathrm{GPa}$, Poisson's coefficient $v=0.3$, firmness $\rho=7830 \mathrm{~kg} \cdot \mathrm{m}^{-3}$, strength $\sigma_{u}=410 \mathrm{MPa}$, limit of fatigue strength $\sigma_{-1}=209 \mathrm{MPa}$. 
In Fig. 3-6 the results of the analysis, by analogy with work [9], of final and element models of serial $(a)$ and maintainable crosspieces $(b)$ are presented.

a)

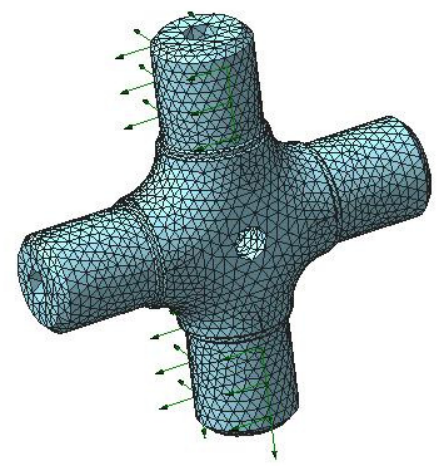

b)

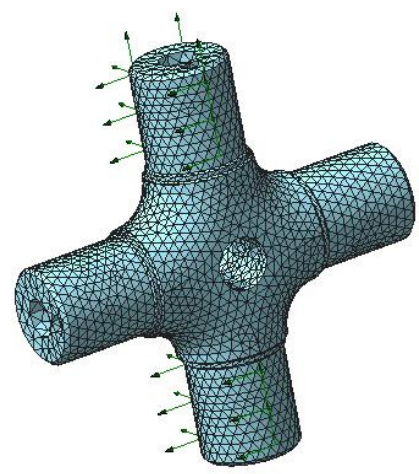

Fig. 3. Final and element models

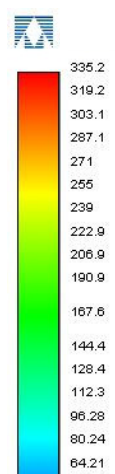

a)
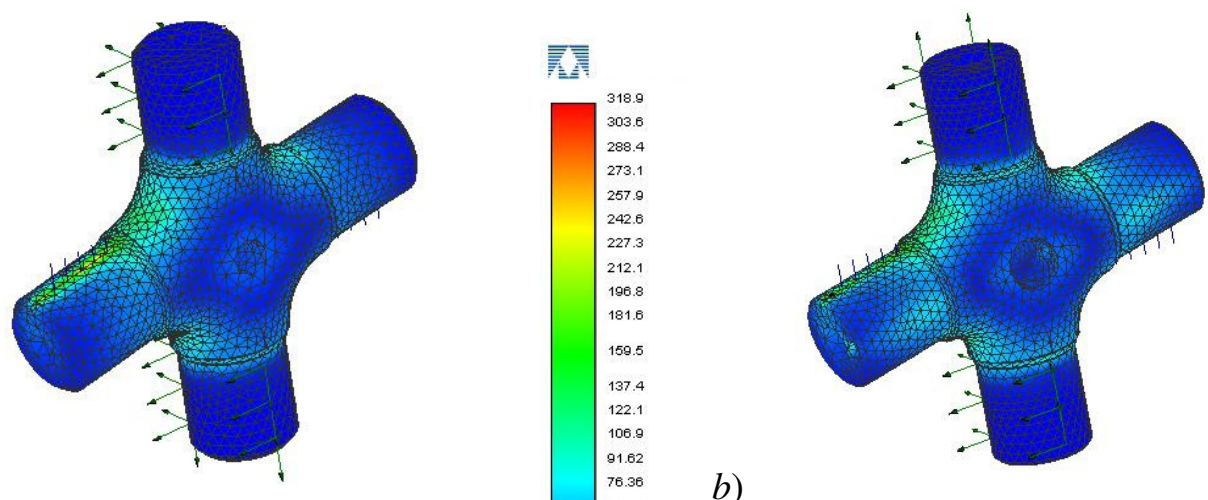

b)

Fig. 4. Equivalent tension according to Mises, MPa
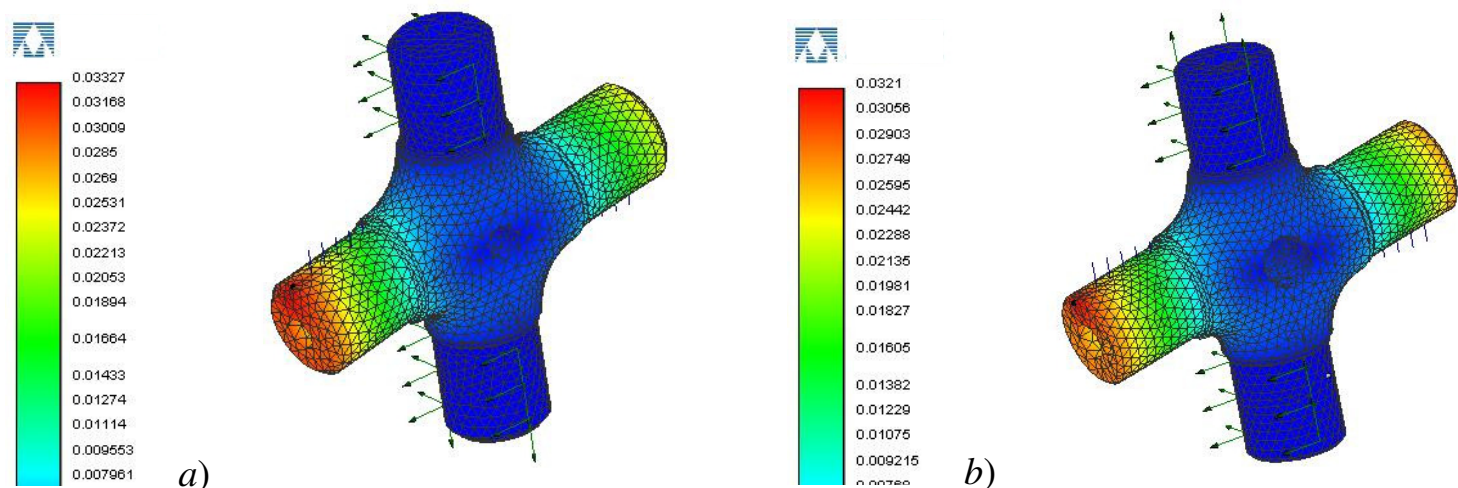

a)

Fig. 5. Total linear conveyances, $\mathbf{m m}$
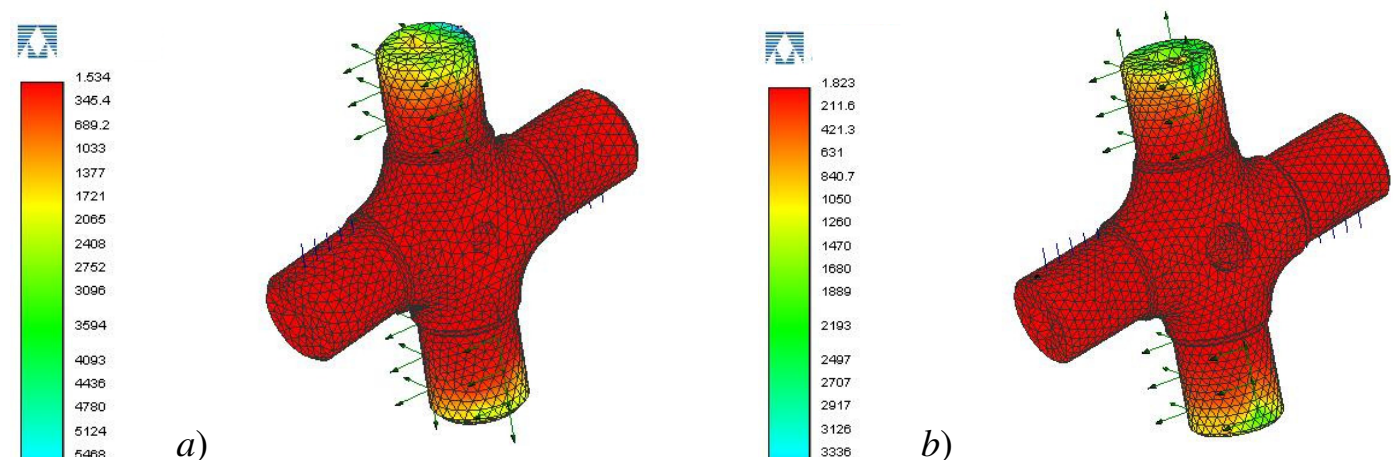

Fig. 6. Reserve factor of fatigue strength

The analysis of the calculation results has shown that the maximum equivalent tension at the repair crosspiece (Fig. 4, $a, b$ ) were $4.8 \%$ lower compared to the serial crosspiece, at the same time, 
the maximum total linear conveyances (Fig. 5, $a, b) 3.7 \%$ lower, and the reserve factor of fatigue strength (Fig. 5, $a, b) 26 \%$ higher, respectively (Table 1). Similar results in studies of the maintainability of the cardan cross design for strength and stiffness parameters were obtained in [10].

Table 1

Results of the comparative final and element analysis (Fig. 4-6)

\begin{tabular}{|c|c|c|}
\hline Parameter & Crosspiece $\boldsymbol{a}$ & Crosspiece $\boldsymbol{b}$ \\
\hline Maximum equivalent tension according to Mises, MPa & 335 & 319 \\
\hline Maximum total linear conveyances, mm & 0.0333 & 0.0321 \\
\hline Reserve factor of fatigue strength & 1.534 & 1.823 \\
\hline
\end{tabular}

\section{Conclusions}

1. On the basis of the patent analysis the options for implementation of methods for improving the maintainability of cardan joints are established.

2. By the final and element analysis of 3D-models of serial and maintainable crosspieces comparative analysis of strength and stiffness characteristics is made:

- maximum equivalent tension according to Mises for the maintainable crosspiece is $319 \mathrm{MPa}$, and for serial $-335 \mathrm{MPa}$, what is $4.8 \%$ lower;

- maximum total linear conveyances of the maintainable crosspiece make $0.0321 \mathrm{~mm}$, and serial $-0.0333 \mathrm{~mm}$, what is $3.7 \%$ lower;

- reserve factor of fatigue strength for the maintainable crosspiece is 1.823 , and for serial 1.534 , what is $26 \%$ higher.

3. The prospects of probes of maintainable crosspieces consist in the subsequent bench tests of prototypes and determination of their real durability.

\section{References}

[1] Lamberson L.R., Kapur K.S. Reliability in engineering design. Weliy India Pvt. Limited, 2009. $608 \mathrm{p}$.

[2] Srivastava A.K., Goering C.E., Rohrbach R.P., Buckmaster D.R. Engineering Principles of Agricultural Machines. $2^{\text {nd }}$ Edition. ASABE, 2006. 553 p.

[3] Erokhin M.N., Pastukhov A.G., Timashov E.P. Analysis of wear of the cardan cross the joints John Deere tractor. Traktori i pogonske mašine, vol. 21, No 1, 2016, pp. 24-29.

[4] Soboyejo W. Mechanical Properties of Engineered Materials. New York. Marcel Dekker, Inc., 2003, $584 \mathrm{p}$.

[5] Кухтов В.Г., Фесун А.А., Шевченко М.А. и др. Оценка напряженно-деформированного состояния карданной передачи привода сельскохозяйственных машин (Assessment of the intense deformed condition of the drive line of drive gear of farm vehicles). Вісник ХНТУСГ ім. П. Василенка, 2012. No 128. pp. 219-225. (In Russian).

[6] Stojanović N., Grujić I., Glišović J., Alempijević A., Narayan S., Kaisan M. Numerical stress analysis of cardan joint for agricultural machinery. Traktori i pogonske mašine, vol. 22, No 1/2, 2018. p. 66-70.

[7] Оптнер С.Л. Системный анализ для решения проблем бизнеса и промышленности. Пер. с англ. М.: Концепт, 2003. 206 с. (Optner C.L. System analysis for business and industrial problem solving. Prenlice-Hall, Inc. Inglewood Clifs, New Jersey, 1965.) (In Russian).

[8] Тимашов Е.П. Совершенствование процессов диагностики узлов трансмиссии автомобилей (Improvement of processes of preliminary treatment of knots of transmission of cars): монография. Белгород: АНО ВО БУКЭП, 2018. 182 c. (In Russian).

[9] Pastukhov A., Kolesnikov A., Bakharev D., Berezhnaya I. Assessment of operability of the crankshaft of the compressor. Engineering for Rural Development. Jelgava, Latvia, 2018. pp. 850855. DOI: 10.22616/ERDev2018.17.N164.

[10] Иванов М.Е., Кукушкин Е.В., Кукушкин С.В., Швалева Н.А. Конечно-элементный анализ крестовин карданных шарниров неравных угловых скоростей (Final and element analysis of crosspieces of cardan joints of unequal angular speeds). Автоматизированное проектирование в машиностроении, 2017, No 5, pp. 78-80. (In Russian). 